This work is licensed under a Creative Commons Attribution-NonCommercial-NoDerivatives 4.0 International License.

\title{
Prospectivity mapping for high sulfidation epithermal porphyry deposits using an integrated compositional and topographic remote sensing dataset.
}

Graham Ferrier ${ }^{1}$, Athanassios Ganas ${ }^{2}$, Richard Pope ${ }^{3}$

${ }^{1}$ Department of Geography, Geology and Environment, University of Hull, Hull, United Kingdom, HU6 7RX.

${ }^{2}$ Institute of Geodynamics, National Observatory of Athens, Lofos Nymfon, Thission, P.O Box 20048, 11810 Athens, Greece.

${ }^{3}$ Geography and Earth Systems Science, University of Derby, Kedleston Road, Derby, United Kingdom, DE22 1GB.

\section{Abstract}

The targeting and discovery of epithermal porphyry mineral deposits can be enhanced using a structured quantitative methodology to analyse the distribution of ore deposits and model their spatial association with exploration evidence providing improved understanding on the controls of ore deposition. A novel exploration tool integrating field and ASTER SWIR and TIR satellite imagery has been developed which provides an enhanced means of resolving surface expressions of the residual silica core of the lithocap. The alteration zones were clearly resolved by the remote sensing data and an intimate spatial relationship between high-grade altered rocks and topographic highs was identified at a number of locations. A Mineral Prospectivity Modelling (MPM) approach, parameterized by the results of the remote sensing study, using a GIS-based weighted linear combination implementation of a Multi-Criteria Evaluation approach and utilising a fuzzy Analytical Hierarchy Process to elucidate expert knowledge has been implemented to target high sulfidation epithermal porphyry deposits on the Island of Lesvos, Greece. The results from this integrated altitudinal-compositional modelling approach closely matched the hydrothermal alteration mapped in the field supporting the accuracy of this MPM approach.

\section{Introduction}


Analysis of the spatial associations of known occurrences of mineral deposits with specific geological features provides insight into the controls on mineral deposit occurrence (de Palomera et al., 2015). Geomorphological features within volcanic terrains provides evidence on both the volcanological and structural evolution and also constrain the potential locations of mineral deposits (Anguita et al., 2001; Aydar et al., 2003; Froger et al., 1998; Lipman, 1992; Milesi et al., 1999; Rytuba, 1994; Saintot et al., 1999; Szekely and Karatson, 2004; Ulusoy et al., 2004). In the case of epithermal porphyry alteration the uppermost silicified-potassic altered zones are relatively resistant to weathering and produce large positive topography anomalies (lithocaps) which are indicative of potential epithermal and/or porphyry mineralization nearby (Chang et al., 2011; Sillitoe, 1994; 2010; Sillitoe and Hedenquist, 2003; White and Hedenquist, 1995).

The identification of these geomorphological features in the field is hampered by the large spatial scale, inaccessible terrain and most significantly because of erosion and tectonism which significantly reduces the amount and clarity of surface expressions of these features (Kouli and St Seymour, 2006; Vamvoukakis et al., 2005). Remote sensing methodologies offer the potential of accurately mapping the diagnostic mineralogical assemblages of the alteration minerals associated with epithermal deposits at landscape scales (e.g. Pour and Hashim, 2012; Rockwell and Hofstra, 2008; Van der Meer et al., 2012). A significant limitation of these remote sensing studies is that the remotely mapped surface expressions of mineralogy are not translated into a clear geological model of ore prospectivity.

This study seeks to develop an enhanced tool for epithermal porphyry alteration mapping integrating remotely mapped mineralogical maps with high spatial resolution topographic data using the results to parameterise a spatial ore prospectivity model of a epithermal porphyry deposit on the Island of Lesvos, Greece.

\section{Geological Setting of the Study Area}

\subsection{Epithermal porphyry mineralisation}

Magmatic-hydrothermal systems associated with arc-type magmatism commonly include a deep magmatic system related to an intermediate composition intrusion that evolves upwards to a more shallow hydrothermal (epithermal) system associated with hot-spring and fumarolic activity 
(Hedenquist and Lowenstern, 1994). High-sulphidation (HS) is one of two principal types of epithermal deposits (e.g. White and Hedenquist, 1995) and maybe separated from the underlying porphyry environment by several hundred vertical metres or may be juxtaposed or even superimposed on it (Sillitoe and Hedenquist, 2003; Sillitoe, 2010). Porphyry mineralization develops in the deeper, magmatic part of this system, whereas epithermal base- or preciousmetal mineralization forms in the more shallow parts of the system (Sillitoe and Hedenquist, 2003; Sillitoe, 2010). Juxtaposition and superimposition of porphyry and HS mineralisation results from telescoping, generally in response to profound surface degradation by uplift-induced erosion or, perphaps less commonly, volcanic collapse during the hydrothermal lifespans of systems (Sillitoe, 1994; 2010; Sillitoe and Hedenquist, 2003). The zones of alteration grade with increasing depth typically from a shallow silic zone through advanced argillic, argillic and finally into a sericitic or phyllic zone (Arribas, 1995).

This alteration sequence occurs over a vertical interval that can range from a few hundred to more than $1000 \mathrm{~m}$ (Arribas, 1995). There is also a lateral alteration zoning characteristic of HS deposits ranging from an innermost zone of vuggy or massive silica which grades into advanced argillic, argillic and finally propylitic. The alteration processes and the location of the HS deposits are intimately spatially associated with the interaction between magmatic processes and structural controls (Hedenquist et al., 1998; Sillitoe and Hedenquist, 2003; Todsal and Richards, 2001). Heald et al., 1987 found the most common regional structural setting was the caldera. Calderas form zones of weakness above a magma chamber providing an excellent pathway for hydrothermal fluids. Association with silicic domes was also identified as being significant (Heald et al., 1987). The nature and extent of this relationship varies markedly between deposits however there are a number of distinct structural, geomorphological and morphological settings which are highly conducive to the formation of epithermal porphyry deposits (Lipman, 1992; Milesi et al., 1999; Rytuba, 1994; White and Hedenquist, 1990).

\subsection{Regional Geological Setting of the Study Area}

The island of Lesvos is located in the East-central Aegean Sea, close to Turkey and occupies an area of $1630 \mathrm{~km}^{2}$ (Fig.1). Lesvos is divided into two distinct geological areas with the northern part composed of thick Miocene post-collisional calc-alkaline volcanic rocks that form stratovolcanoes that extend SW-NE across the centre of the island (Fig. 1) (Pe-Piper., 1980a; 1980b; Pe-Piper and Piper, 1993; Pe-Piper et al., 2014). The volcanic sequence according to Pe-Piper (1980a; 1980b) is: (a) Lower lava unit: andesites, basalts, dacites, zones of intense hydrothermal alteration; (b) Acidic 
volcanics: pyroclastics, ignimbrites and rhyolites; (c) Upper lava unit: basalts, andesites and dacites; (d) Intrusions: dacite plugs. The southern part of the island hosts the oldest rocks on the island and consists of low-grade metamorphic rocks (mainly schists) with intercalations of marbles, limestones, quartzites and metamorphosed volcanic rocks (Kontas et al., 1994). The age of these rocks is Early Carboniferous to Triassic and they are metamorphosed to pumpellyite-actinolite and greenschist grade (Kontas et al., 1994). Six caldera have been identified in the northern part of Lesvos (Fig. 1), (Kouli and St Seymour, 2006). In the western part of the study area a major elliptical caldera, Sigri, is bordered by smaller satellite calderas of Mesotopos, Agra and Skalohori (Kouli and St Seymour, 2006). The potential locations for mineral prospectivity are associated with the volcanic rocks therefore this study will be focused on the northern part of Lesvos.

\section{Materials and Method}

While most of the available spatial datasets are limited to surface expressions of the mineral systems, topography, and geological features the combination of these datasets with expert knowledge and spatial analysis methods can provide insights into the ore-forming processes. Mineral Prospectivity Mapping (MPM) provides a structured quantitative methodology to integrate these multiple spatial datasets to analyse the distribution of mineral deposits and model their spatial association providing insights into the controls on ore deposition e.g. (de Palomera et al., 2015; Bonham-Carter et al., 1988; Carranza, 2009; Carranza and Sadeghi, 2010; Listin, 2015; Zhang et al., 2017; Zuo et al., 2015). MPM can utilise either a data- and knowledge-driven approach or some combination of both (Brown et al., 2003). There are a number of methods available for the integration of evidence in data-driven approaches including logisitic regression (Chung and Agterberg, 1980), weights of evidence (Bonham-Carter et al., 1989) and neural networks (Porwal et al., 2003) while knowledge-based approaches utilise methods such as analytical hierarchy process (Harris et al., 2001) and fuzzy logic (An et al., 1991). A number of GIS-based Multi-Criteria Evaluation (MCE) methods are available that can be used in MPM including Boolean overlay and weighted linear combination (WLC) (Gorsevski et al., 2012). Fuzzy set theory (Zadeh, 1965) when combined with WLC methods e.g. (Zhang et al., 2017; Gorsevski et al., 2012) provides an approach for overcoming the limitation of using threshold values in standard Analytical Hierarchy Process (AHP) approaches (Saaty, 1987).

A WLC MCE approach has been implemented in this study to map prospectivity for epithermal deposits. Based on previous studies and expert knowledge the key criteria for identifying epithermal 
deposits on Lesvos were identified as being the lithology, radial faulting the presence and type of alteration and the spatial association with volcanological-related structures at the landscape and site scales. Analogue maps of the lithology, hydrothermal alteration and faulting were digitized and georegistered using $\operatorname{ArcGIS}^{\mathrm{TM}}$. A fuzzy AHP approach was used to elicit knowledge on the distances and the relative importance (weighting) of the spatial associations of epithermal mineralization with lithology, hydrothermal alteration and volcanological-related structures. This knowledge was used to produce fuzzy maps of the spatial influence of these different criteria and to combine them using the allocated weights in $\operatorname{ArcGIS}^{\mathrm{TM}}$.

\subsection{Lithology and Structures}

Lithological evidence was extracted from the Greek Geological Survey mapping service 1:50,000 geological maps supported by additional mapping information from published research (e.g. PePiper., 1980a; 1980b; Pe-Piper and Piper, 1993; Pe-Piper et al., 2014; Vamvoukakis et al., 2001). Using a Digital Elevation Model (DEM) generated from 1:50000 contour map and the results of previous published research (Kouli and St Seymour, 2006) the presence and location of faults associated with the caldera (ring and radial) were identified. A slope layer was generated from the DEM. The slope and contour layers were used with cross-sectional analysis to resolve the location and dimension of lava domes within the calderas and presence of potential unidentified caldera. Volcanic lithologies were considered favourable for mineralisation.

\subsection{Hydrothermal Alteration}

An extensive field spectral mapping campaign was carried out in May 2010 and a representative set of rock hand specimens was acquired. An Analytical Spectral Devices (ASD) FieldSpec Pro FR spectroradiometer was used to collect field and laboratory spectra. The ASD has a spectral range of $0.35-2.5 \mu \mathrm{m}$ with sampling intervals of $1.4 \mathrm{~nm}$ at $0.35-1.0 \mu \mathrm{m}$ and $2 \mathrm{~nm}$ at $1.0-2.5 \mu \mathrm{m}$ and full width half maximum spectral resolutions of $6 \mathrm{~nm}$ at VNIR wavelengths and $11 \mathrm{~nm}$ at SWIR wavelengths. Absolute reflectance values were calculated by calibrating each batch of $\sim 20$ repeat measurements against a Spectralon white reference panel. The effect of compositional heterogeneity on sample 
spectrum was mitigated by averaging evenly spaced repeat measurements taken from across sample surfaces.

\subsection{ASTER data processing}

ASTER Short Wave InfraRed (SWIR) surface reflectance (AST-07XT) and ASTER spectral emittance (AST_05) data (Abrams, 2000, Rowan et al, 2006) were used in this study. The spectral emittance data were co-registered with the SWIR data by applying a $6 \times$ pixel duplication of the TIR data. The sea, vegetated and Quaternary cover areas were masked out. A Minimum Noise Function (MNF) transformation followed by a Pixel Purity Index (PPI) analysis was applied, using the functionality implemented in ENVI 5.1 ${ }^{\mathrm{TM}}$, which extracted the image endmembers and their spatial distribution (Boardman, 1993; 1998). Spatial mapping and abundance estimates for specific alteration zones was carried out using the Mixture Tuned Matched Filtering (MTMF) technique on the SWIR and Spectral Emittance ASTER images separately (Green et al., 1988).

\subsection{MPM Implementation}

Table 2 shows the pairwise comparison matrix of relative importance and weights associated with the geological criteria. The hydrothermal alteration layer, comprising only the higher grade advanced argillic and silicified layers was multiplied by the assigned weighting. The highest weights were assigned to the hydrothermal alteration and the in-caldera domes which are the most important criteria. The Consistency Ratio (CR) is $<0.1$ which indicates a good consistency of the judgements used for the comparison.

\section{Results}

\subsection{Analysis of Topographic Data}


An analysis of the DEM resolved the six caldera and the numerous felsic post-collapse volcanic domes bordering the Mesotopos and Stipsi calderas identified in previous studies (Figs.2 and 3), (Kouli and St Seymour, 2006; Vamvoukakis et., 2001). Two circular features to the east of the Vatoussa caldera at Anemotia and Parakia were identified (Fig. 3). Cross sections of these circular features illustrate similar topographic profiles to the Agra and Mesotopos calderas with steep outward facing slopes at the edges and the presence of dome structures on the caldera floor (Figs. 3 and 4). The circular features at Anemotia and Parakia generally have steep inward facing walls but are breached towards the Bay of Kalloni on their southwestern edges. Analysis of the slope and DEM layers strongly suggests that these two circular features are also calderas however a detailed field study is required to confirm this.

\subsection{Analysis of Field Spectral Dataset}

The field spectra displays the diagnostic spectral features characteristic of alteration zones of epithermal deposits (Fig. 5). Spectrum $1\left(39^{\circ} 08.25 ; 2^{\circ} 01.51\right)$ from the advanced argillic zone exhibits very strong absorption features indicative of a very high concentration of alunite whereas spectrum $2\left(39^{\circ} 08.15 ; 26^{\circ} 02.17\right)$ from the argillic zone exhibits very strong absorption features indicative of a high concentration of kaolinite. Spectrum $3\left(39^{\circ} 18.24 ; 26^{\circ} 13.29\right)$ located at the edge of the argillic altered zone exhibits much less distinct absorption doublets at 2160 and $2200 \mathrm{~nm}$ indicative of a lower concentration of kaolinite while spectrum $4\left(39^{\circ} 08.15 ; 26^{\circ} 02.17\right)$ exhibiting weaker absorption doublet at 2160 and $2200 \mathrm{~nm}$ indicating an presence of montmorillonite with decreasing kaolinite content. The wavelength location of the alunite $1480 \mathrm{~nm}$ absorption feature was constant at $1480 \mathrm{~nm}$ in all the spectra indicating a consistent pure K-alunite composition (Bishop, 2005).

\subsection{Analysis of ASTER Datasets}

To resolve the presence and relative proportion of vegetation in the study area an NDVI image was generated using the ASTER VNIR imagery (Fig. 6). A significant proportion of the study area is covered in extensive vegetation ranging from pine forests, Mediterranean scrub to farmland with Mesotopos and the western part of the Stipsi calderas having the least vegetation cover. The 
presence of this dense vegetation cover has a critical effect on the utility of remote sensing geological mapping approaches as only locations where there are significant gaps in the vegetation cover allow the underlying geology to be resolved as demonstrated by the main and the inset images in Figure 5 where the highly altered rocks (shaded white) are very distinct.

The field spectra resampled to the ASTER wavelengths retain definition of the most intense absorption features particularly the intense absorption feature centered near $2205 \mathrm{~nm}$ (Fig. 7). The different alteration zones and the intensity gradation within an individual alteration zone are differentiable despite the significant decrease in spectral resolution. The highest intensity advanced argillic spectrum has a single differentiable feature centered on $2165 \mathrm{~nm}$. With decreasing intensity, shown by the loss of alunite in the mineral assemblage the spectrum exhibits a pronounced doublet absorption feature which extends from 2165 to $2205 \mathrm{~nm}$. With decreasing intensity within the argillic zone the absorption feature centered at $2205 \mathrm{~nm}$ initially becomes narrower and more pronounced while in the lowest intensity spectra the absorption feature has weakened significantly.

Only three spectral endmembers were identified from the MNF and PPI analysis of the ASTER TIR imagery representing the silicified (quartz), advanced argillic (alunite-kaolinite) and country rock (Fig. 8). The spectra representative of the silicified alteration zone shows the distinctive, intense, broad emissivity minimum between bands 10 and 12 characteristic of a very high quartz content. The spectra representative of the advanced argillic alteration zone shows a distinctive emissivity minimum in band 12 but with higher values in bands 10 and 11 . The spectra representative of the country rock showed a relatively flat emissivity profile. Spectral endmembers representing the argillic and propylitic alteration zones were not identifiable.

The results of the MTMF analysis of the SWIR imagery are shown in Figs. 9 and 10 where the degree of match is indicated by higher numbers representing good matches and vice versa (Boardman, 1993; 1998). Pixels corresponding to the highest degree of match for each class were transferred digitally to the aerial photography mosaic and assigned a colour. Determination of the threshold range to represent each class was based on the coherence of the spatial distribution of pixels and lack of widely scattered pixels. Pixels that are not colour-coded were not classified to a specific landcover or rock type. Despite the significant reduction in spectral resolution in the ASTER SWIR data compared to the ASD data a clear gradation within the advanced argillic altered rocks was clearly identifiable because of the high alunite concentrations and the excellent rock exposure. The argillic alteration zones are usually smaller in extent and are often found peripheral to the advanced argillic outcrops. The ASTER TIR data identified the silicified zones clearly. 
To investigate the spatial and topographic relationship of the alteration zones mapped from the ASTER SWIR and TIR datasets cross-sections across the Mesotopos and Stipsi calderas with the values from the MTMF analysis plotted with the topographic profile were (Figs. 9,10,11,12). In the Mesotopos caldera (Figs. 9 and 10) a transect north-to-south across the caldera shows a number of distinct topographic highs mapped as lava domes by Kouli and St Seymour, 2006. The plot of the MTMF scores for the silicified and higher grade advanced argillic zones and the topography along this transect are shown in Fig. 9. The silicified zone MF scores are very closely associated with the topographic highs at $2440 \mathrm{~m}$ and $5230 \mathrm{~m}$ while the higher grade advanced argillic MF scores are similarly associated with the topographic highs at $2440 \mathrm{~m}$ and $5230 \mathrm{~m}$ but extend further out than the silicified zone peaks. The distribution of the alteration zones in the Stipsi and Mesotopos calderas are significantly different (Fig. 11). In the northwest of the Stipsi caldera a large discrete outcrop of advanced argillic altered rock is present with no associated silicified or lower grade advanced argillic or argillic. A transect (labelled C-D) in Fig. 12 shows a very clear association of the advanced argillic outcrop with a topographic high within the caldera (Fig. 12a). In the southeast of the Caldera a large discrete outcrop of silicified altered rock is present with no associated advanced argillic or argillic zone outcrops. A transect (labelled E-F) in Fig. 11 again shows a very clear association of the silicified outcrop with a topographic high (Fig. 12b).

\subsection{Integration of the MPM modelling with Field-based studies}

The distribution of the field mapped alteration zones as mapped by the Greek Geological Survey (Bitzios, 1998) is intimately associated with the volcanological-related structures (Fig. 13). The Mesotopos and Vatoussa calderas have the clearest association with almost all the altered rocks contained within the caldera rims. The Stipsi caldera has been only partially mapped on the western side where again there is a very close association with the caldera rim. The Agra caldera is largely made up of low grade Kaolinite-alunite altered rock whereas the Skalohori caldera has no surface expression of the altered rock. The area of altered rock east of Vatoussa is located within the rims of the two proposed calderas at Anemotia and Parakia (Fig. 13).

The Stipsi area is characterized by intense hydrothermal alteration, ranging from propylitic to argillic and locally to silic (Kelepertsis and Esson, 1987). A dacitic andesite porphyry body in the western part has been altered to kaolinite, illite and smectite (Voudouris and Alfieris, 2005). Latestage milky to amesthystine quartz and platy calcite veins with pyrite and galena were formed along 
the major NNE-SSW trending fault zone, and have overprinted earlier-formed alteration and mineralisation. Barren jasperiod silic alteration which overlies altered volcanic is well exposed at higher elevations to the north. Rokos et al., 2000 identified a full alteration sequence at Stipsi (Table 3). Kontis et al., 1994 studied an active geothermal system at Megala Therma area on the northern coast of Lesvos. This location displayed the complete alteration sequence from silicification to phyllic associated with quartz veins up to $10 \mathrm{~m}$ wide.

The integration of the results of the MPM modelling with the field mapping results showed a very good spatial correlation in the Mesotopos and Stipsi calderas. In the Mesotopos caldera the highest model values are almost all within silicified zone areas with the lower model values extending out in into the high Grade Kaolinite and some into the low grade kaolinite-alunite field-mapped zone (Figs. 14 and 15). In the Stipsi caldera again the highest model values fit completely within the silicified and high grade kaolinite zones.

The presence of extensive vegetation cover over most of the study area limits the use of the results of remote sensing based mineralogical mapping. To implement the MPM modelling over the rest of the study area means utilising the field mapped hydrothermal alteration zones. The results of the modelling using the field mapped alteration zones show that distinct areas of high mineral prospectivity are located across a large continuous area in the centre of the study and in smaller, discrete areas in the Stipsi and Mesotopos calderas (Fig. 16).

\section{Discussion}

Epithermal porphyry deposits are often characterized by having a complex horizontal and vertical pattern of alteration zones (Arribas, 1995; White and Hedenquist, 1995; Sillitoe and Hedenquist, 2003; Sillitoe, 2010). The differential resistance to erosion of the different types of alteration has been widely utilised by exploration geologists (e.g. Chang et al., 2011; Rae et al., 2003). The three-dimensional complexity in alteration patterns (Rytuba, 1994) combined with the large size, inaccessibility issues and often indistinct surface features can make accurate interpretation of the extent and nature of the alteration patterns using only field-based mapping approaches difficult. The potential of satellite remote sensing-based approaches to accurately map the alteration zones associated with epithermal porphyry deposits at site-to-landscape scales have been widely demonstrated (e.g. Aubakar et al., 2018; Pour et al., 2018; Rowan et al., 2006) but these studies have often been limited to mapping the surface expressions of the ore deposits. In this study a key objective was to investigate the potential of an integrated remote sensing approach to identify 
silicified lithocaps representative of the residual silica core (Kilias et al., 2001; Milesi et al., 1999; Vamvoukakis et al., 2001; 2005; Voudouris and Alfieris, 2005).

In the Mesotopos caldera the different alteration zones are intimately spatially associated with a continuous gradation from the silicified, through the different grades of advanced argillic to the argillic zones. In the Mesotopos caldera transect A-B showed that the distribution of the silicified and the highest grade advanced argillic alteration zones was closely associated with the localized topographic highs within the caldera structures probably because of their resistance to erosion (Figs. 9 and 10). This integrated dataset provides the critical information to enable interpretation of the horizontal and vertical variation of alteration grade with regard to their spatial relationship to the hydrothermal core (Vamvoukakis et al., 2001; 2005). In the Stipsi caldera there are discrete, outcrops of advanced argillic rocks on the western side and silicified rocks on the eastern side of the caldera with no other associated alteration zones (Figs. 11 and 12). The silicified outcrop is associated with a lava dome whereas the high grade advanced argillic outcrop is quite close to a radial fault. The lack of a range of alteration zones could therefore be due to the ore deposit being constrained by the location of emplacement (Yasami et al., 2017). The silicified and higher grade advanced argillic zones at the top of the topographic highs could have limited erosion exposing the underlying lower grade alteration zones. This study has demonstrated the potential of a remote mapping tool to assist identification of silicified lithocaps at landscape scales.

In this study an integrated compositional-altitudinal MPM approach utilising remote sensing data, where available, has been implemented to integrate the wide variety of available spatial geological data and transform it into a more complex spatial data product able to improve the targeting and discovery of mineral deposits. The limited availability of information on the presence of mineralisation in the study area meant that more data-driven MPM approaches such as Random Forest (Harris et al., 2015) could not be applied. The MCE approach implemented utilised a knowledge-based approach (Harris et al., 2015) providing a highly flexible mechanism for importing and processing a wide range of spatial datasets within a GIS environment (Zhang et al., 2017). The results of the MPM modelling are supported by the clear spatial association with the field mapped hydrothermal zones at both the landscape and site scales. In both the Mesotopos and the Stipsi calderas the highest values modelled cells fall within the silicified and high grade kaolinite - alunite zones. A critical potential weakness in the MCE MPM approach is the range and quality of the knowledge utilised in the modelling. While this can be mitigated to some extent by methods such as fuzzy AHP (Zhang et al., 2017) additional improvements would be beneficial. The results of the MCE MPM implemented in this study could be improved by (a) inclusion of other data layers, such as geochemistry and geophysics that were not used in this study; (b) implementation of a multi- 
scenario modelling approach which would allow the sensitivity of the model results to variation in the key criteria to be quantitatively assessed and (c) more detailed understanding of the influence of the faulting on the spatial distribution of epithermal porphyry related alteration (Eastman et al., 1995).

\section{Conclusions}

This study has demonstrated that data reduction methodologies offer a structured quantitative methodology to integrate a wide variety of complex spatial datasets to analyse the distribution of mineral deposits and model their spatial association providing insights into the controls on ore deposition as well as assisting understanding of the geology at the landscape scales. The potential of satellite SWIR and TIR data, integrated with high spatial resolution topographic data, to resolve silicified lithocaps at the landscape scale provides a powerful new exploration tool. The presence of vegetation cover and the spatial resolution of the ASTER TIR imagery does inhibit this approach however hyperspectral and very high spatial resolution multispectral satellite imagery offers the potential of significantly improving the remote mapping capabilities in the near future. The knowledge-based MCE MPM approach implemented in this study offers an exploration approach without a priori knowledge of mineral deposits in the study area, as in this study. The results of the MPM modelling showed a very clear spatial correlation to field-based mapping of the alteration zones in both the Mesotopos and Stipsi calderas.

\section{Acknowledgements}

This research was supported by a grant award from the Leverhulme Trust and by loans of field spectrometers from the NERC Field Spectroscopy Facility. The authors would like to thank the two anonymous reviewers for their constructive suggestions and corrections to the manuscript.

\section{References}


Abrams, M., 2000. The Advanced Spaceborne Thermal Emission and Reflection Radiometer (ASTER) - data products for the high spatial resolution imager on NASA's EOS-AM1 platform: International Journal of Remote Sensing 21, 847-861.

An, P., Moon, W., Rencz, A.N., 1991. Application of fuzzy theory for integration of geological, geophysical and remotely sensed data. Can. J. Explor. Geophys. 27, 1-11.

Andrada de Palomera, P., van Ruitenbeek, F.J., Carranza, E.J.M., 2015. Prospectivity for epithermal gold-silver deposits in the Deseado Massif, Argentina, Ore Geol. Rev. 71, 484-501.

Anguita, F., Verma, S.P., Marquez, A., Vasconcelos-F., M., Lopez, I., Laurrieta, A., 2001.

Circular features in the Trans-Mexican Volcanic Belt. J. Volcanol. Geotherm. Res. 107, 265-274.

Arribas, A., 1995. Characteristics of high-sulfidation epithermal deposits, and their relation to magmatic fluid, In Magmas, Fluids, and Ore Deposits, Ed.: J.F.H. Thompson. Mineralogical Association of Canada Short Course, 23, pp. 419-454.

Aubakar,A.J., Hasim, M., Pour, B.A., 2018. Identification of hydrothermal alteration minerals associated with geothermal system using ASTER and Hyperion satellite data: a case study from Yankari Park, NE Nigeria. Geocarto International. 2018.

Aydar, E., Gourgaud, A., Ulusoy, I., Digonnet, F., Labazuy, P., Sen, E., Bayhan, H., Kurttas, T., Tolluoglu, A.U., 2003. Morphological analysis of active Mount Nemrut stratovolcano, eastern Turkey: evidences and possible impact areas of future eruption. J. Volcanol. Geotherm. Res. 123, 301-312. Azizi, H., Tarverdi, M.A., Akbarpour, A., 2010. Extraction of hydrothermal alterations from ASTER SWIR data from east Zanjan, northern Iran, Advances in Space Research. 46, 99-109.

Bishop, Janice., 2005. The visible and infrared spectral properties of jarosite and alunite. American Mineralogist. 90, 1100-1107.

Bitzios, G., 1998. Greek Geological Survey, Unpublished Geological Mapping Report.

Boardman, J.W., 1993. Automating spectral unmixing of AVIRIS data using convex geometry concepts, in Summaries fourth Annual. JPL Airborne Geoscience Workshop, JPL Pub. 93-26, NASA Jet Propulsion Laboratory, 11-14.

Boardman, J.W., 1998. Leveraging the high dimensionality of AVIRIS data for improved subpixel target unmixing and rejection of false positives: mixture tuned matched filtering, in Summaries of the seventh JPL airborne Geoscience workshop. JPL Pub. 97-1, NASA Jet Propulsion Laboratory, 5556.

Bonham-Carter, G.F., Agterberg, F.P., Wright, D.F., 1988. Integration of geological datasets for gold exploration in Nova Scotia. Photogramm. Eng. Remote Sens. 54 (77), 1585-1592. 
Bonham-Carter, G.F., Agterberg, F.P., Wright, D.F., 1989. Weights of evidence modeling: a new approach to mapping mineral potential. In: Agterberg, F.P., Bonham-Carter, G.F., (Eds.). Statistical Applications in the Earth Sciences. Geological Survey of Canada, Paper 89-9, pp. 171-183.

Brown, W.M., Groves, D., Gedeon, T., 2003. Use of fuzzy membership input layers to combine subjective geological knowledge and empirical data in a neural network layer method for mineralpotential mapping. Nat. Resour. Res. 12 (3), 183-200.

Carranza, E.J.M., Hale, M., 2002. Where are the porphyry copper deposits spatially localized? A case study in Bengeut province, Philippines. Nat. Resour. Res. 11 (2), 45-59.

Carranza, E.J.M., 2009, Controls on mineral deposit occurrence inferred from analysis of their spatial pattern and spatial association with geological features. Ore Geol. Rev. 35, 383-400.

Carranza, E.J.M., Sadeghi, M,. 2010. Predictive mapping of prospectivity and quantitative estimation of undiscovered VMS deposits in Skelleft district, (Sweden). Ore Geol. Rev. 38, 219-241.

Chang, D., 1996. Application of the extent analysis method on fuzzy AHP. Eur. J. Oper. Res. 95, 816832.

Chang, Z., Hedenquist, J.W., White, N.C., Cooke, D.R., Roach, M., Deyell, Cl., Garcia, J., Gemmell, J.B., McKnight, S., Cuison, A.L. 2011. Exploration tools for linked porphyry and epithermal deposits: Example from the Mankayan intrusion-centered Cu-Au district, Luzon, Phillipines. Econ. Geol 106: 1365-1398.

Chung, C.F., Agterberg, F.P., 1980. Regression models for estimating mineral resources from geological map data. Math. Geol. 12, 473-488.

Eastman, J. R., Jin; K., Yem., P. A. K.; Toledano, J. 1995. Raster procedures for multi-criteria/multiobjective decisions. Photogrammetric Engineering and Remote Sensing. 61: 539-47.

Ferrier, G., White, K., Griffiths, G., Bryant, R., Stefouli, M., 2002. The mapping of hydrothermal alteration zones on the island of Lesvos, Greece using an integrated remote sensing dataset, International Journal of Remote Sensing, 23:2, 341-356.

Froger, J.-L., Lenat, J.-F., Chorowicz, J., Le Pennec, J.-L., Bourdier,J.-L., Kose, O., Zimitoğlu, O., Gundogdu, N.M., Gourgaud, A., 1998. Hidden calderas evidenced by multisource geophysical data; example of Cappadocian Calderas, Central Anatolia. J.

Volcanol. Geotherm. Res. 185, 99-128.

Green, A. A.; Berman, M.; Switzer, P.; Craig, M. D., 1988. A transformation for ordering multispectral data in terms of image quality with implications for noise removal. IEEE Transactions on Geoscience and Remote Sensing, 26, 65-74. 
Gorsevski, P.V., Donevska, K.R., Mitrovski, C.D., Frizado, J.P., 2012. Integrating multi-criteria evaluation techniques with geographic information systems for landfill site selection: A case study using ordered weighted average. Waste Management, 32, 287-296.

Harris, J.R., Wilkinson, L., Heather, K., Fumerton, S., Bernier, M.A., Ayer, J., Dahn, R., 2001. Application of GIS processing techniques for producing mineral prospectivity maps - a case study: Mesothermal Au in the Swayze greenstone belt, Ontario. Can. J. Earth Sci. 43, 865-893.

Harris, J.R., Grunsky, E., Behnia, P., Corrigan, D., 2015. Data- and knowledge-driven mineral prospectivity maps for Canada's North. Ore Geology Reviews. 71, 788-803.

Heald, P., Foley, N.K., O'Hayba, D. 1987. Comparative anatomy of volcanic-hosted epithermal deposits: Acid-Sulfate and Adularia-Sericite Types. Economic Geology 82, 1-26.

Hedenquist, J.W., Lowenstern, J.B. 1994. The role of magmas in the formation of hydrothermal ore deposits. Nature $370,519-527$.

Hedenquist, J.W., Arribas, A., Reynolds, T.J. 1998. Evolution of an Intrusion-Centered Hydrothermal System: Far Southeast-Leptano Porphry and Epithermal Cu-Au Deposits, Philippines, Economic Geology 93, 4, 373-404.

Kelepertsis, A.E., Esson ,J., 1987. Major- and trace element mobility in altered volcanic rocks near Stypsi, Lesvos, Greece and genesis of a kaolin deposit. Appl. Clay Sci 2: 11-28.

Kilias, S.P., Naden, J., Cheliotis, I., Shepherd, T.J., Constandinidou, H., Crossing, J., Simos, I. 2001. Epithermal gold mineralisation in the active Aegean volcanic arc: the Profitis Ilias deposit, Milos Island, Greece. Miner. Deposita. 36, 32-44.

Kontis, E., Kelepertsis, A,E., Skounakis, S. 1994. Geochemistry and alteration facies associated with epithermal precious metal mineralization in an active geothermal system, northern Lesvos, Greece. Min Deposita 29 : 430-433.

Kouli, M., St Seymour, K. 2006. Contribution of remote sensing techniques to the identification and characterisation of Miocene caldera, Lesvos Island, Aegean Sea, Hellas. Geomorphology, 44 1-16. Lipman, P.W., 1992. Ash-flow calderas as structural controls of ore deposits-recent work and future problems. U.S. Geol. Soc. Bull. L1-L12.

Lisitin, V., 2015. Spatial data analysis of mineral deposit point patterns: applications to exploration targeting. Ore Geol. Rev. 71, 861-881.

Milesi, J.-P., Marcoux, E., Sitorous, T., Simandjuntak, M., Leroy, J.,Bailly, L., 1999. 
Pongkor (West Java, Indonesia): a Pliocene supergene-enriched epithermal Au-Ag-(Mn) deposit. Miner. Depos. 34, 131-149.

Najafi, A., Karimpour, M.H., Ghaderi, M., 2014. Application of fuzzy AHP method to IOCG prospectivity mapping: a case study in Taherbad prospecting area, eastern Iran. Int. J. Appl. Earth Observation Geoinformation 33, 142-154.

Pe-Piper, G., 1980a. Geochemistry of Miocene shoshonites, Lesvos, Greece. Contrib. Mineral. Petrol. 72, 387-396. Berlin.

Pe-Piper, G., 1980b. The Cenozoic volcanic sequence of Lesvos, Greece. Z. Dtsch. Geol. Ges. 131, 889-901.

Pe-Piper, G., Piper, D.J.W., 1993. Revised stratigraphy of the Miocene volcanic rocks of Lesvos, Greece. N. Jb. Geol. Paläont. Mh H2, 97-110.

Pe-Piper, G., Zhang, Y., Piper, D.J.W., Prelevic, D., 2014. Relationship of Mediterranean type lamproites to large shoshonite volcanoes, Miocene of Lesbos, NE Aegean Sea. Lithos 184-187, 281299.

Porwal, A., Carranza, E.J.M., Hale, M., 2003. Artificial neural networks for mineral prospectivity mapping: a case study from Aravalli Province, Western India. Nat. Resour. Res. 12, 156-171.

Pour, A.M., Hashim, M. The application of ASTER remote sensing data to porphyry copper and epithermal gold deposits, Ore Geol. Rev. 2012, 44, 1-9.

Pour, A.B., Park, Y., Park, T.S., Hong, J.K. Hashim, M., Woo, J., Ayoobi, I. 2018a. Evaluation of ICA and CEM algorithms with Landsat-8/ASTER data for geological mapping in inaccessible regions. Geocarto International.

DOI: $10.1080 / 10106049.2018 .1434684$.

Rae, A.E., Cooke, D.R., Phillips, D., Yeats, C., Ryan, C., Hermoso, D. 2003. Spatial and temporal relationships between hydrothermal alteration assemblages at the Palinpinon geothermal field, Phillipines: implications for porphyry and epithermal ore deposits. Society of Economic Geologists Special Publication 10: 223-246.

Rockwell, B.W., Hofstra, A.H., 2008. Identification of quartz and carbonate minerals across northern Nevada using ASTER thermal emissivity data - Implications for geologic mapping and mineral resource investigations in well-studied and frontier areas, Geosphere, 4, 1, 218-246. Rokos, D., Argialas, D., Mavrantza, R., St-Seymour, K., Vamvoukakis, C., Kouli, M., Paraskevas, H., Karfakis, I., Denes, G., 2000, Structural Analysis for Gold Mineralization using Remote Sensing and Geochemical Techniques in a GIS environment: Island of Lesvos, Hellas, Nat. Resour. Res. 9, 277-293. 
Rowan, L.C., Schmidt, R.G., Mars, J.C. 2006., Distribution of hydrothermally altered rocks in the Reko Diq, Pakistan mineralized area based on spectral analysis of ASTER data, Remote Sens. Environ. 104 $74-87$.

Rytuba, J.J., 1994. Evolution of volcanic and tectonic features in caldera settings and their importance in the localization of ore deposits. Econ. Geol. 89, pp. 1687-1696.

Saintot, A., Angelier, J., Chorowicz, J., 1999. Mechanical significance of structural patterns identified by remote sensing studies: a multiscale analysis of tectonic structures in Crimea. Tectonophysics 313, 187-218.

Saaty, R.W., 1987. The analytic hierarchy process - what is it and how it is used, Mathematical Modelling 9, 3-5, 161-176.

Sillitoe, R.H., 1994. Erosion and collapse of volcanoes: Causes of telescoping in intrusion-centered ore deposits, Geology 22, 10, 945-948.

Sillitoe, R.H., Hedenquist, J.W., 2003. Linkages between Volcanotectonic Settings, Ore-Fluid Compositions, and Epithermal Precious Metal Deposits, Society of Economic Geologists, Special Publication 10.

Sillitoe, R.H., 2010. Porphyry copper systems. Economic Geology 105, 3-41.

Szekely, B., Karatson, D., 2004. DEM-based morphometry as a tool for reconstructing primary volcanic landforms: examples from the Borzsony Mountains, Hungary. Geomorphology 63, 25-37. Todsal, R.M., Richards, J.P. 2001. Magmatic and Structural Controls on the Development of Porphyry $\mathrm{Cu}+$ /- Mo +/- Au Deposits, Society of Economic Geologists Reviews 14, 157-181.

Ulusoy, I., Cubukcu, E., Aydar, E., Labazuyb, P., Gourgaud, A., Vincent, P.M., 2004. Volcanic and deformation history of the Bodrum resurgent caldera system (southwestern Turkey). J. Volcanol. Geotherm. Res. 136, 71-96.

Van der Meer, F., van der Werff, H.M.A., van Ruitenbeek, F.J.A.., Hecker, C.A., Bakker, W.H., Noomen, M.F., van der Meijde, M., Carranza, E.J.M., Boudewijn de Smeth, J., Woldai, T., 2002. Multiand hyperspectral geologic remote sensing: A review, International Journal of Applied Earth Observation and Geoinformation 14, 112-128.

Vamvoukakis, C., St-Seymour, K., Williams-Jones, A., Rokos, D., 2001. The Miocene Caldera of Stipsi on Lesvos Volcano: an example of "high sulfidation" hydrothermal system explored for gold, Abstract in Volume, Geological Association of Canada-Mineralogical Association of Canada (GACMAC), Annual Meeting May 2001, St. John's, New Foundland, Canada.

Vamvoukakis C., K, St., Kouli, M., Lamera, S., Denes, G., 2005. Investigation of non pristine volcanic structures acting as probable hosts to epithermal gold mineralization in the back arc region of the 
active Aegean arc, using combined satellite imagery and field data: examples from Lesvos volcanic terrain, Developments in Volcanology 7, 329-343.

Voudouris, P., Alfieris, D., 2005. New Porphyry - Cu +/- Mo occurrences in the north-eastern Aegean: Ore mineralogy and epithermal relationships, In: Mao J, Bierlein FP (eds) Mineral deposit research: Meeting the global challenge. Springer Verlag, 473-476.

White, N.C., Hedenquist, J.W., 1990. Epithermal environments and styles of mineralization: variations and their causes, and guidelines for exploration. J. Geochem. Explor. 36 pp. 445-474. White, N.C., Hedenquist, J.W., 1995. Epithermal gold deposits: Styles, characteristics and exploration, SEG Newsletter 23:1, 9-13.

Yasami, N., Ghaderi, M., Madanipour, S., Taghilou, B, 2017. Structural control on overprinting highsulfidation epithermal on porphyry mineralisation in the Chodarchay deposit, northwestern Iran. Ore Geology Reviews, 86, 212-224.

Zadeh, L.A., 1965. Fuzzy sets. Inf. Control 8 (3), 338 - 353.

Zhang, N., Zhou, K., Du, X., 2017. Application of fuzzy logic and fuzzy AHP to mineral prospectivity mapping of porphyry and hydrothermal vein copper deposits in the Dananhu-Tousuquan island arc, Xinjiang, NW China, Journal of African Earth Sciences 128, 84-96.

Zuo, R., Zhang, Z.J., Zhang, D.J., Carranza, E.J.M., Wang, H.C., 2015. Evaluation of uncertainity in mineral prospectivity mapping due to missing evidence: a case study with skarn-type Fe deposits in Southwestern Fujian Province, China. Ore Geol. Rev. 71, 502-515. 


\begin{tabular}{|l|l|l|l|}
\hline Factor & Weight & Spatial Influence & Fuzzy Function \\
\hline $\begin{array}{l}\text { Lithology: epithermal deposits only } \\
\text { located in volcanics }\end{array}$ & 1 & Within volcanics & None - Binary \\
\hline $\begin{array}{l}\text { Caldera: association with caldera } \\
\text { significant geographical constraint }\end{array}$ & 1 & $\begin{array}{l}\text { Inside and within } \\
200 \mathrm{~m}\end{array}$ & $\begin{array}{l}1.0 \text { inside : linear } \\
\text { outside }\end{array}$ \\
\hline $\begin{array}{l}\text { Radial Fault: line of weakness within } \\
\text { caldera promoting hydrothermal fluid } \\
\text { flow }\end{array}$ & 1 & within $100 \mathrm{~m}$ & Linear \\
\hline $\begin{array}{l}\text { In-caldera dome: } \text { morphological and } \\
\text { structurally highly important in the } \\
\text { hosting of epithermal deposits }\end{array}$ & 2 & $\begin{array}{l}\text { Inside and within } \\
10\end{array}$ & $\begin{array}{l}1.0 \text { inside : linear } \\
\text { outside }\end{array}$ \\
\hline $\begin{array}{l}\text { Hydrothermal Alteration: pixels classified } \\
\text { as being in the Silicified and the Higher } \\
\text { grade Advanced Argillic Zone }\end{array}$ & 4 & $0 \mathrm{~m}$ & Within pixel \\
\hline
\end{tabular}

Table 1 Recognition criteria for epithermal deposits on the Island of Milos, with relative weightings and extent and nature of spatial influence. 


\begin{tabular}{|l|l|l|l|l|l|l|}
\hline & Lithology & Caldera & $\begin{array}{l}\text { Radial } \\
\text { Fault }\end{array}$ & $\begin{array}{l}\text { In-caldera } \\
\text { dome }\end{array}$ & $\begin{array}{l}\text { Hydrothermal } \\
\text { Alteration }\end{array}$ & Weights \\
\hline Lithology & 1 & 1 & 1 & $1 / 2$ & $1 / 4$ & 0.111 \\
\hline Caldera & 1 & 1 & 1 & $1 / 2$ & $1 / 4$ & 0.111 \\
\hline Radial Fault & 1 & 1 & 1 & $1 / 2$ & $1 / 4$ & 0.111 \\
\hline In-caldera dome & $2 / 1$ & $2 / 1$ & $2 / 1$ & 1 & $2 / 4$ & 0.222 \\
\hline $\begin{array}{l}\text { Hydrothermal } \\
\text { Alteration }\end{array}$ & $4 / 1$ & $4 / 1$ & $4 / 1$ & $4 / 2$ & 1 & 0.444 \\
\hline
\end{tabular}

Table 2 A pairwise comparison matrix for calculation of the criteria weights for the epithermal deposit site selection 


\begin{tabular}{|l|l|}
\hline Zone & Mineral Assemblage \\
\hline Silicified & Quartz, Muscovite, Galena, Sphalerite, Copper Oxides \\
\hline Advanced Argillic & Kaolinite and alunite \\
\hline Argillic & Illite, montmorillonite and kaolinite \\
\hline Propylitic & Epidote, chlorite and iron oxides \\
\hline
\end{tabular}

Table 3 Mineralogy of alteration zones at Stipsi, (Rokos et al., 2000). 


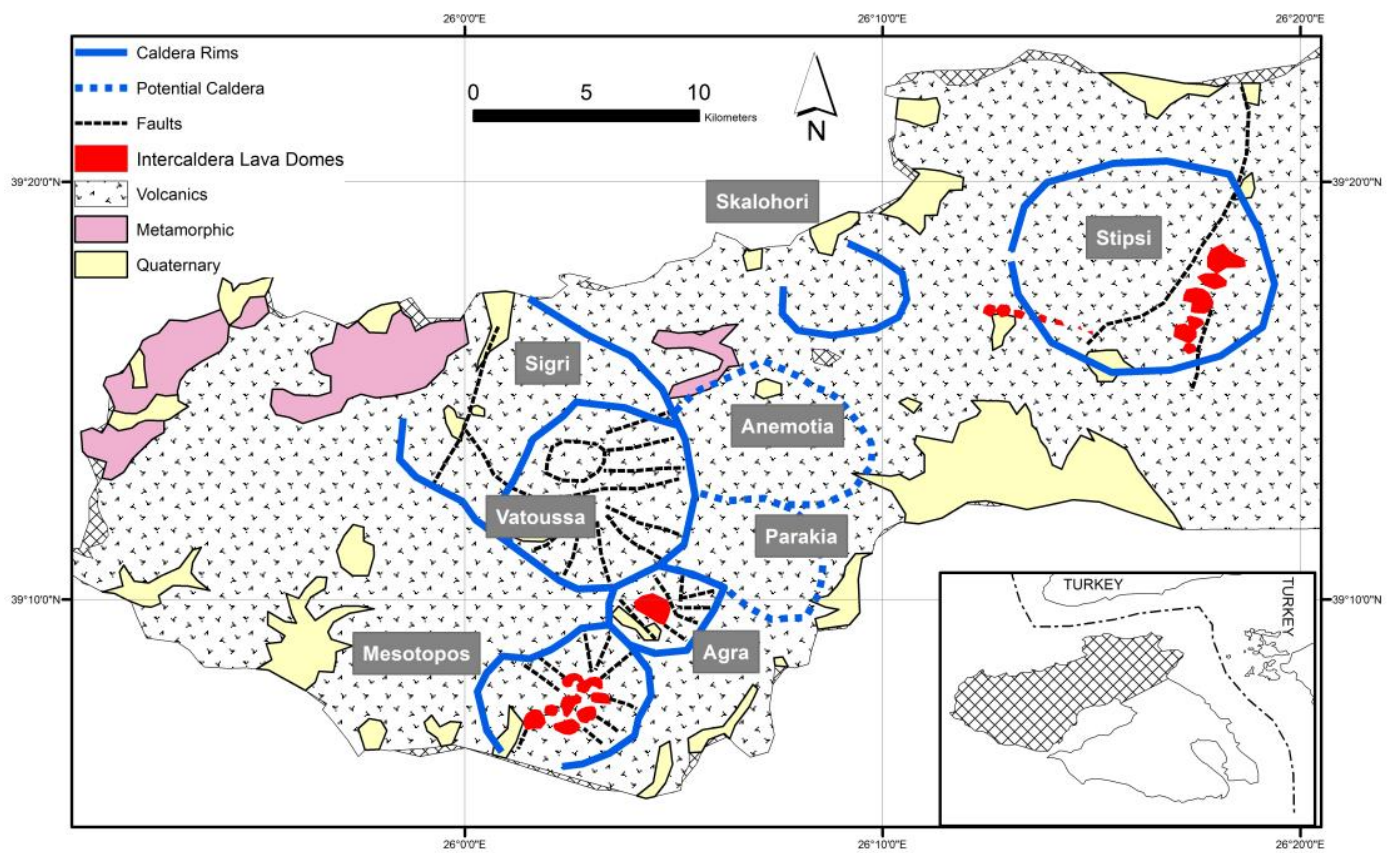

Fig. 1. Location and geology of the Study Area (after Kouli and St Seymour, 2006). 


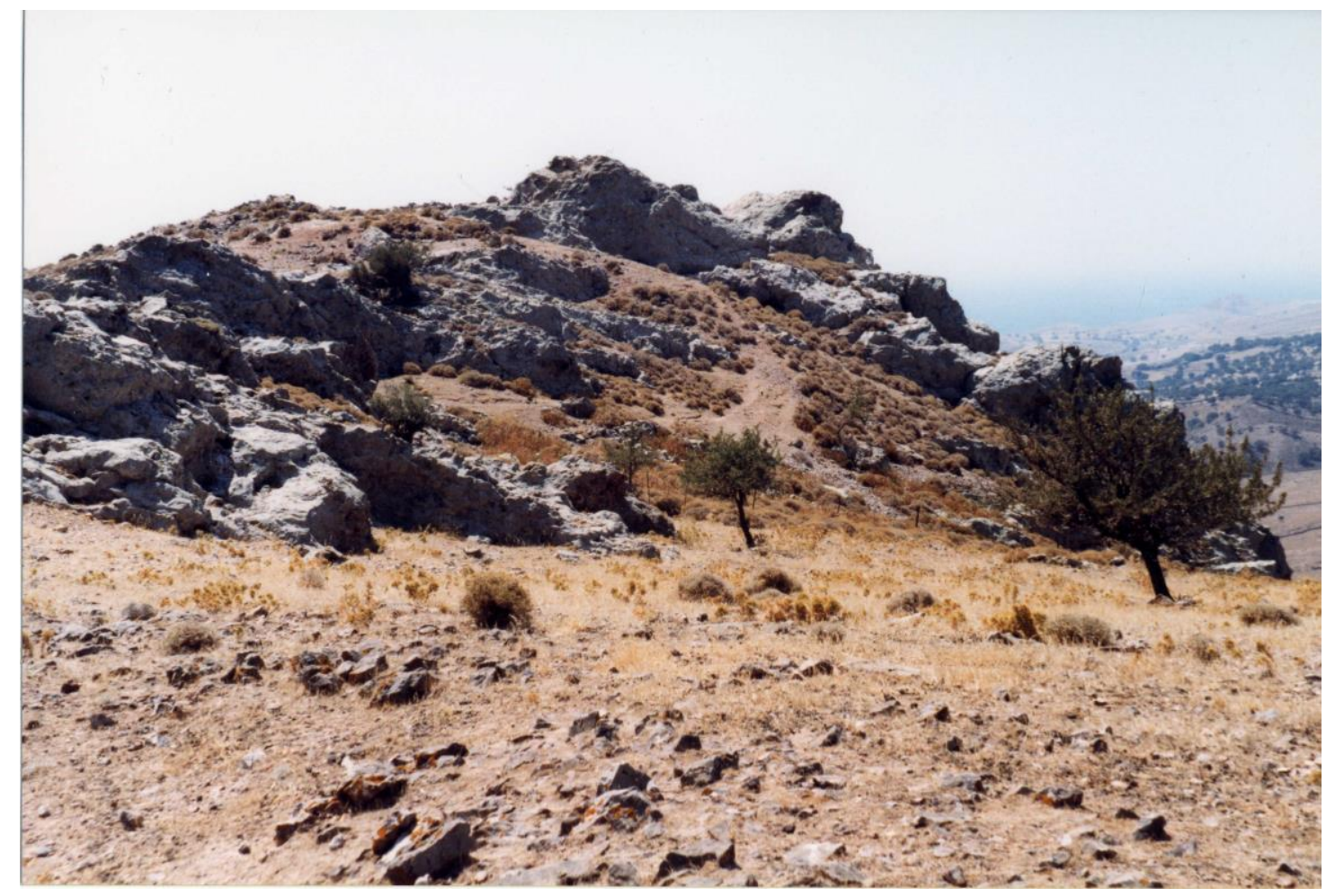

Fig. 2. View of a post-collapse volcanic dome in the Mestopos Caldera looking southwest to the Bay of Kalloni $\left(26.041^{\circ}, 39.166^{\circ}\right)$. 


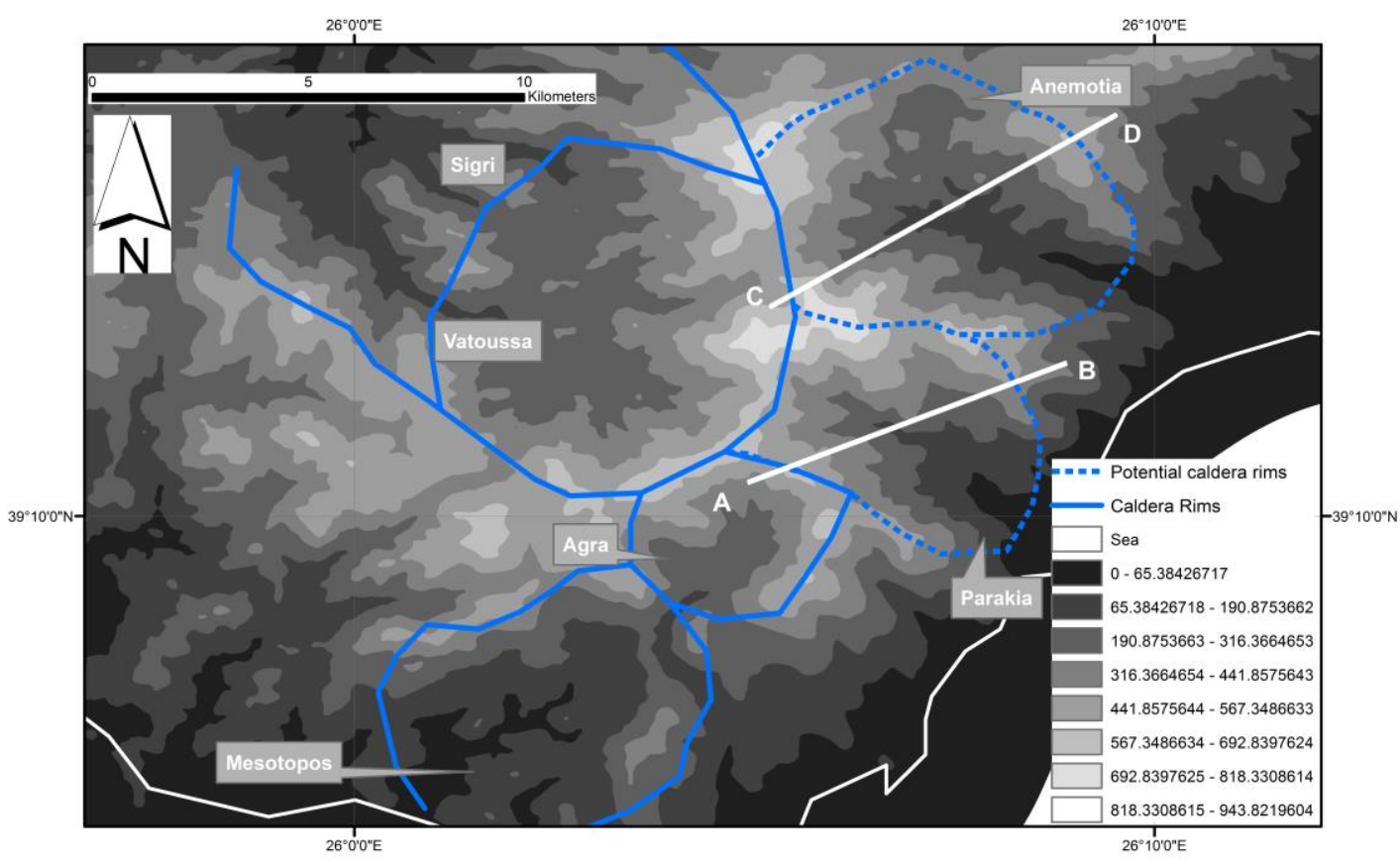

Fig. 3 Topography of northwest Lesvos with identified and potential caldera rims overlain. 

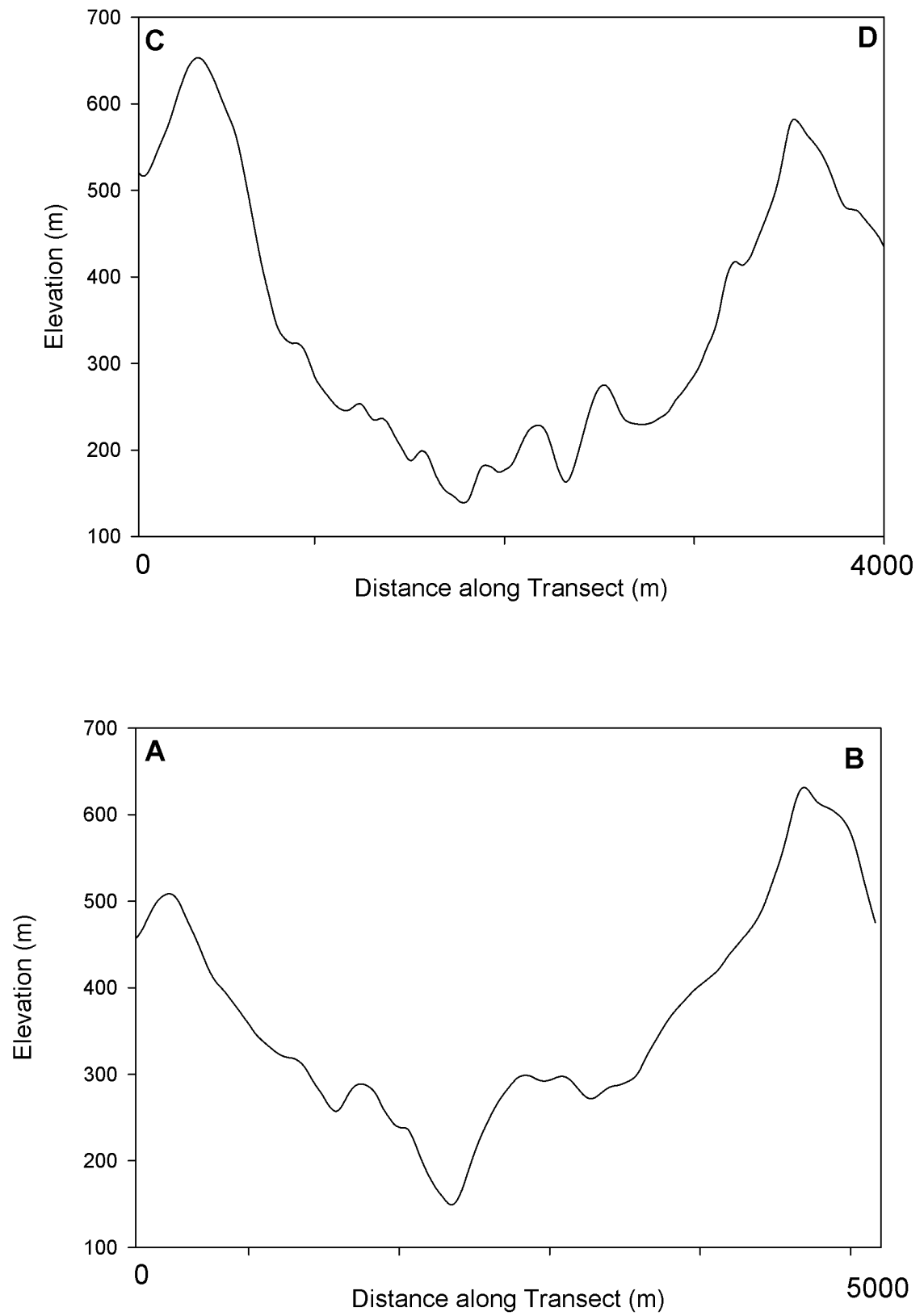

Fig. 4 Cross sections across potential calderas at Anemotia and Parakia. 


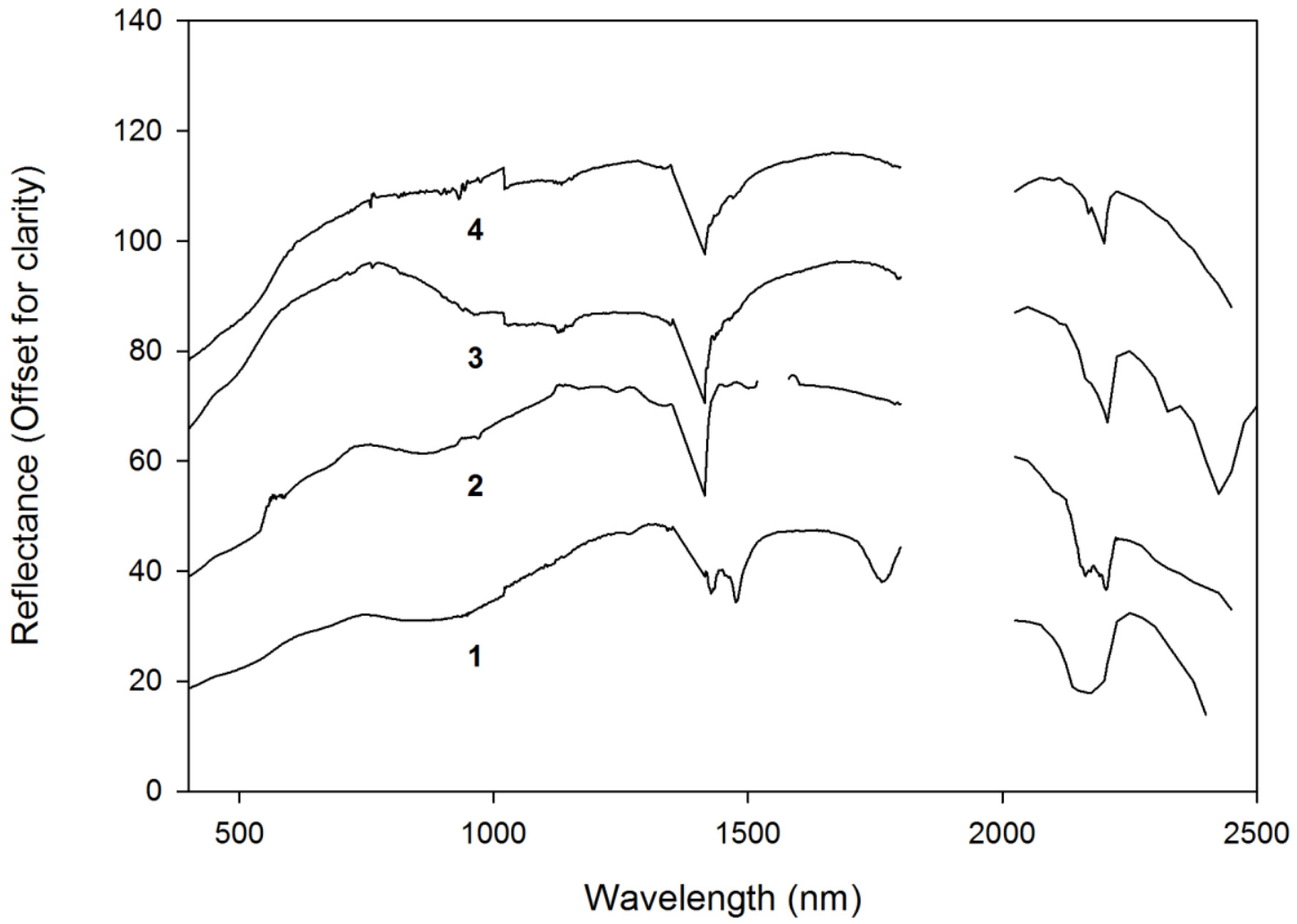

Fig.5. Field spectra from Lesvos. 


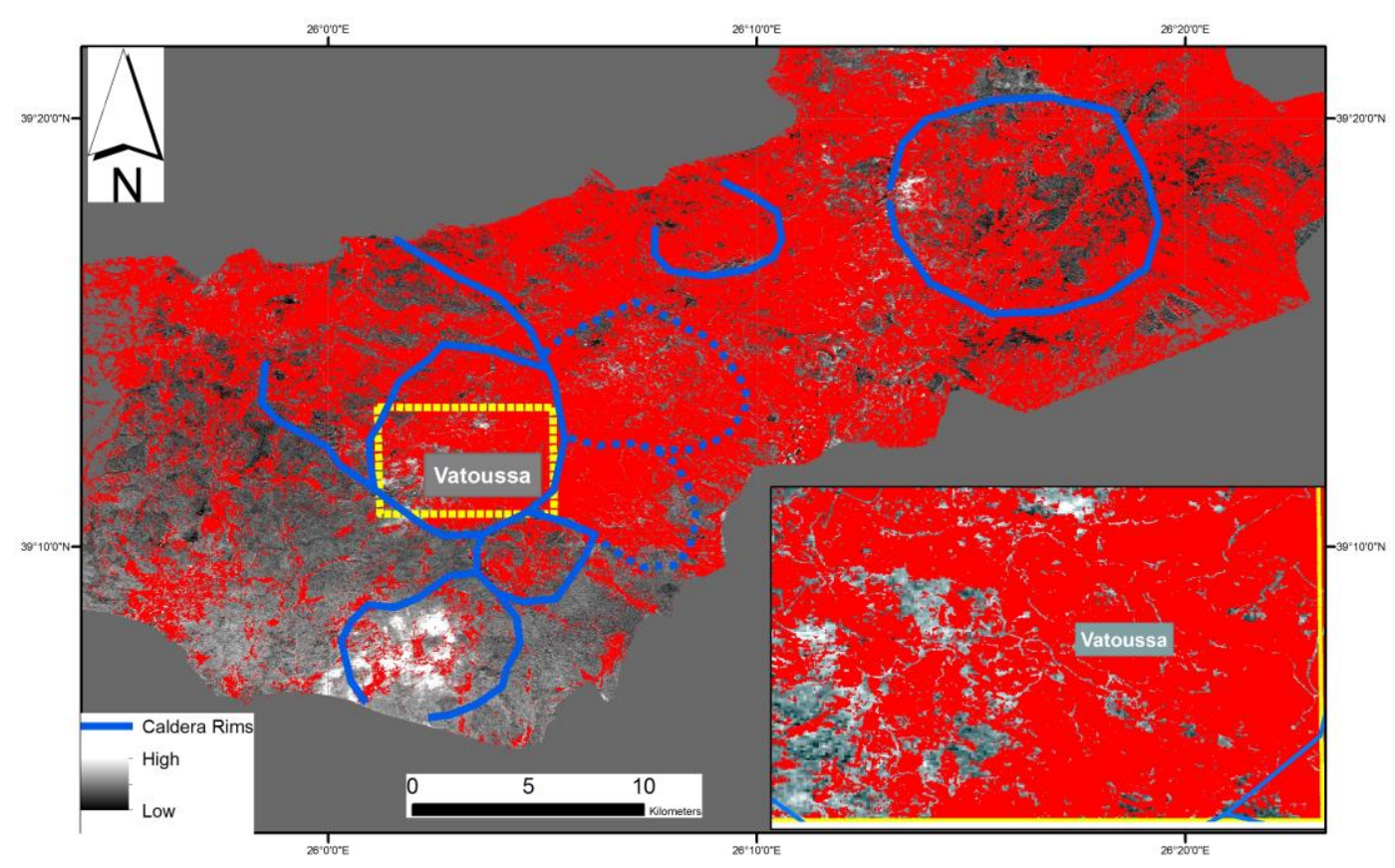

Fig. 6. NDVI Image of study area derived from ASTER VNIR image 


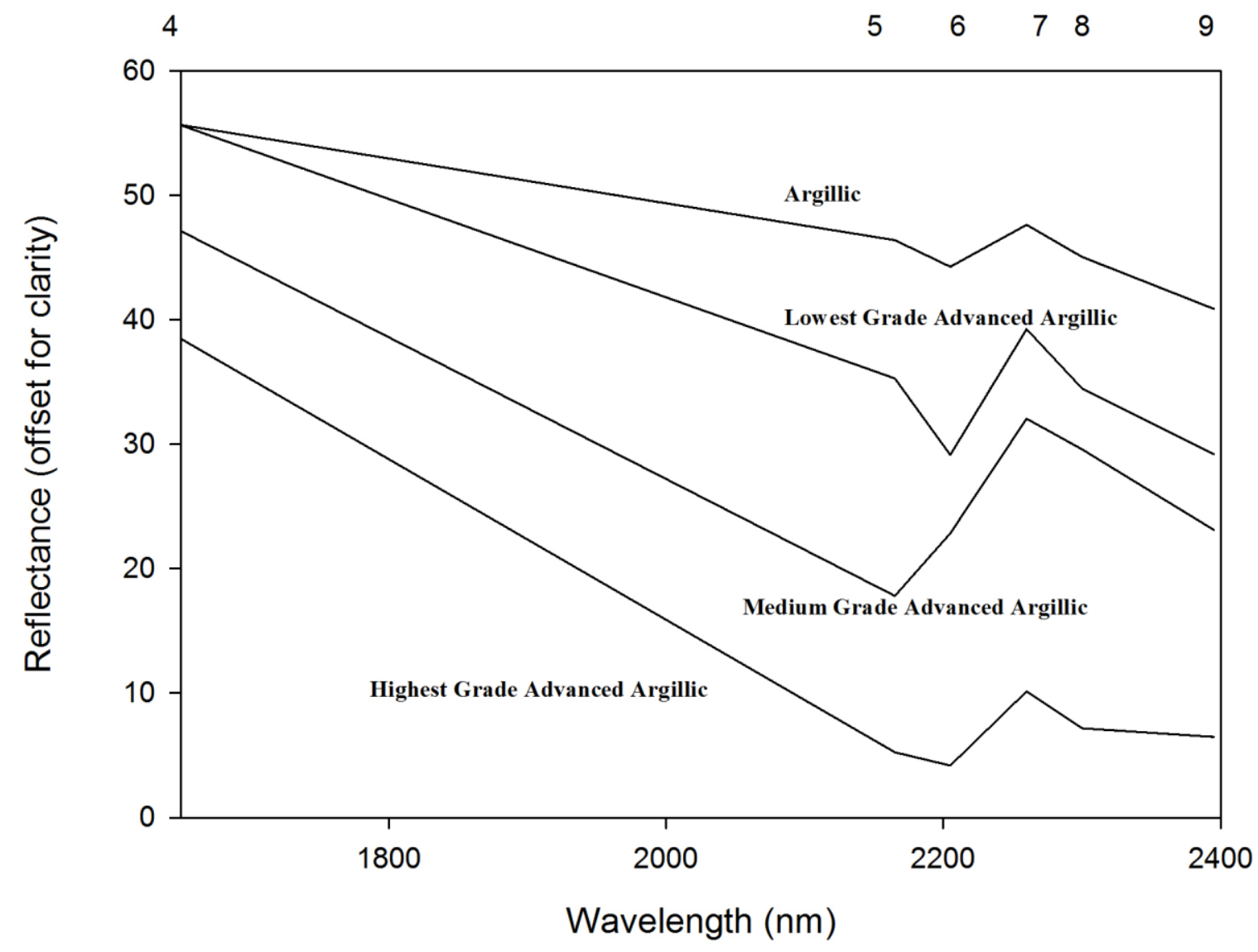

Fig. 7. Field spectra resampled to the ASTER SWIR bandwidths. 


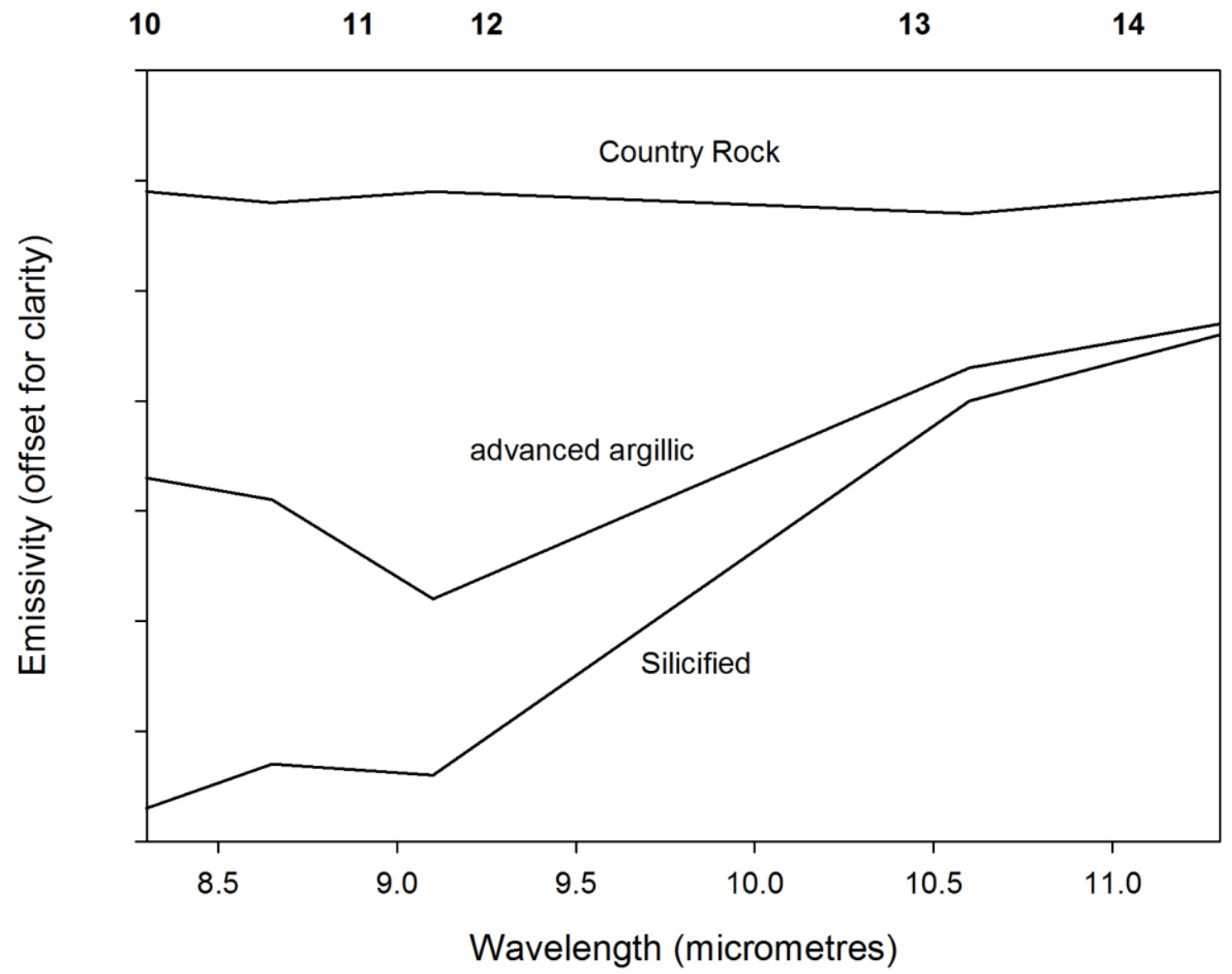

Fig. 8. ASTER image spectra used as reference in match-filter processing of TIR data. 


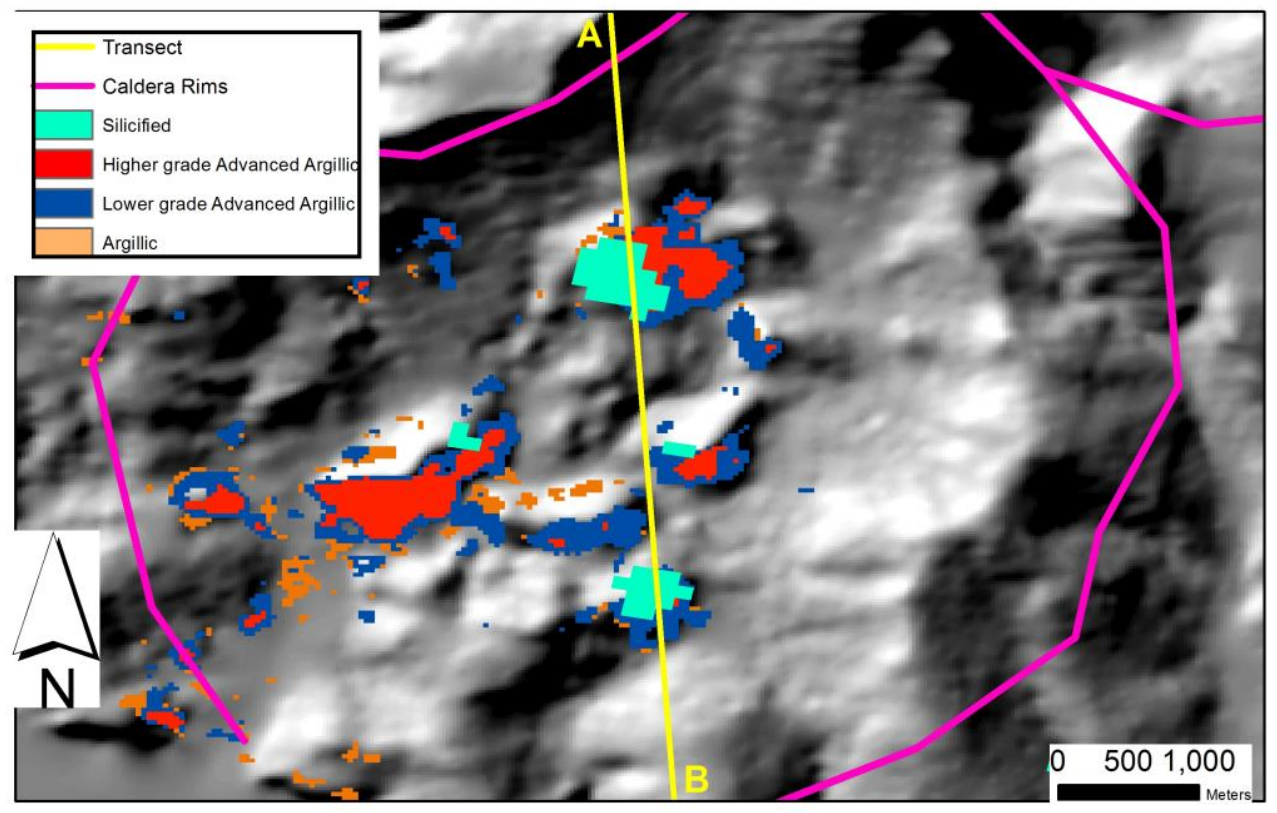

Fig. 9. MF results for ASTER SWIR \& TIR data for Mesotopos with Transect A-B shown. 


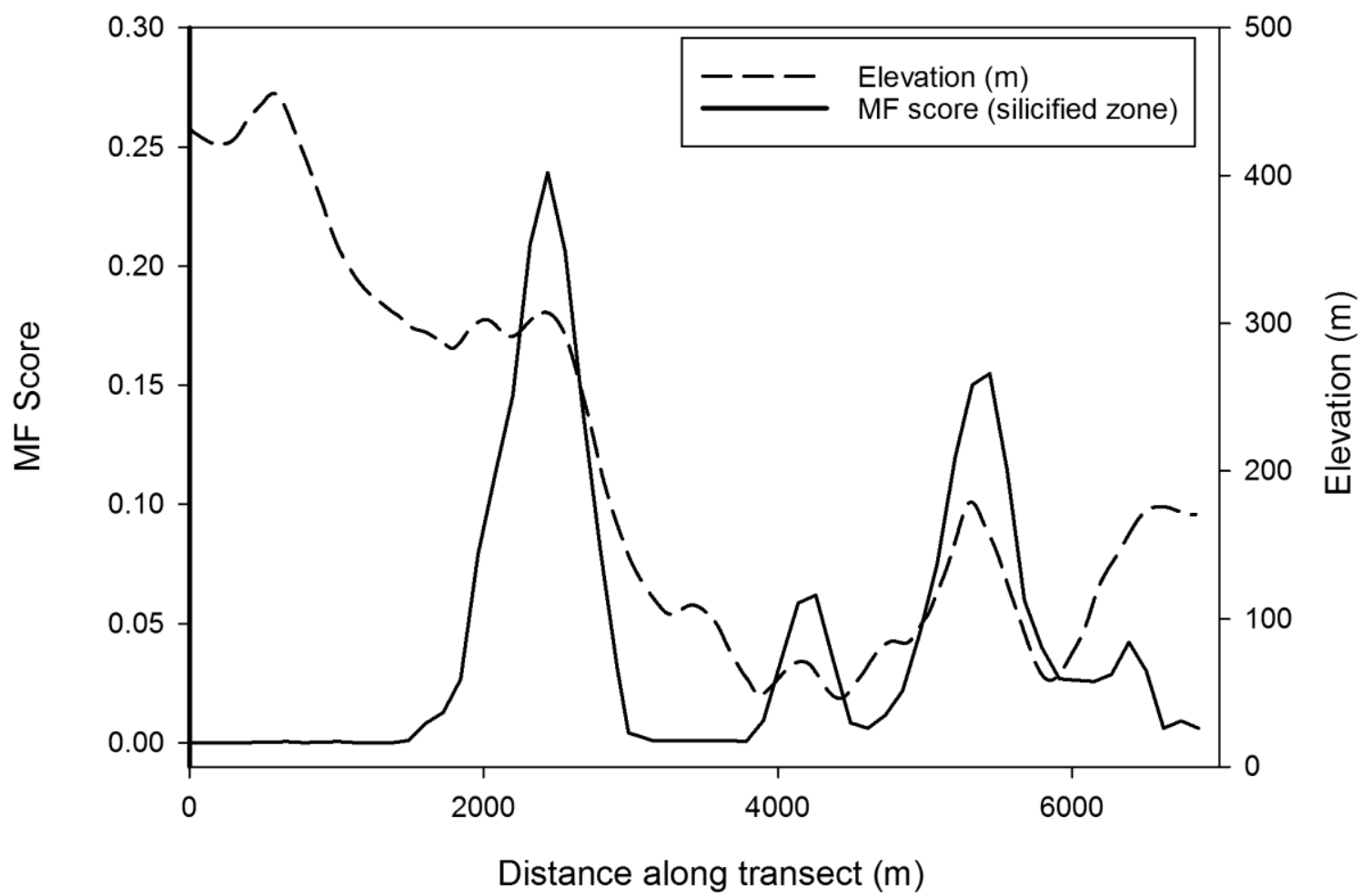

Fig. 10. Transect (A-B) across Mesotopos caldera showing topography and MTMF score (silicified zone). 


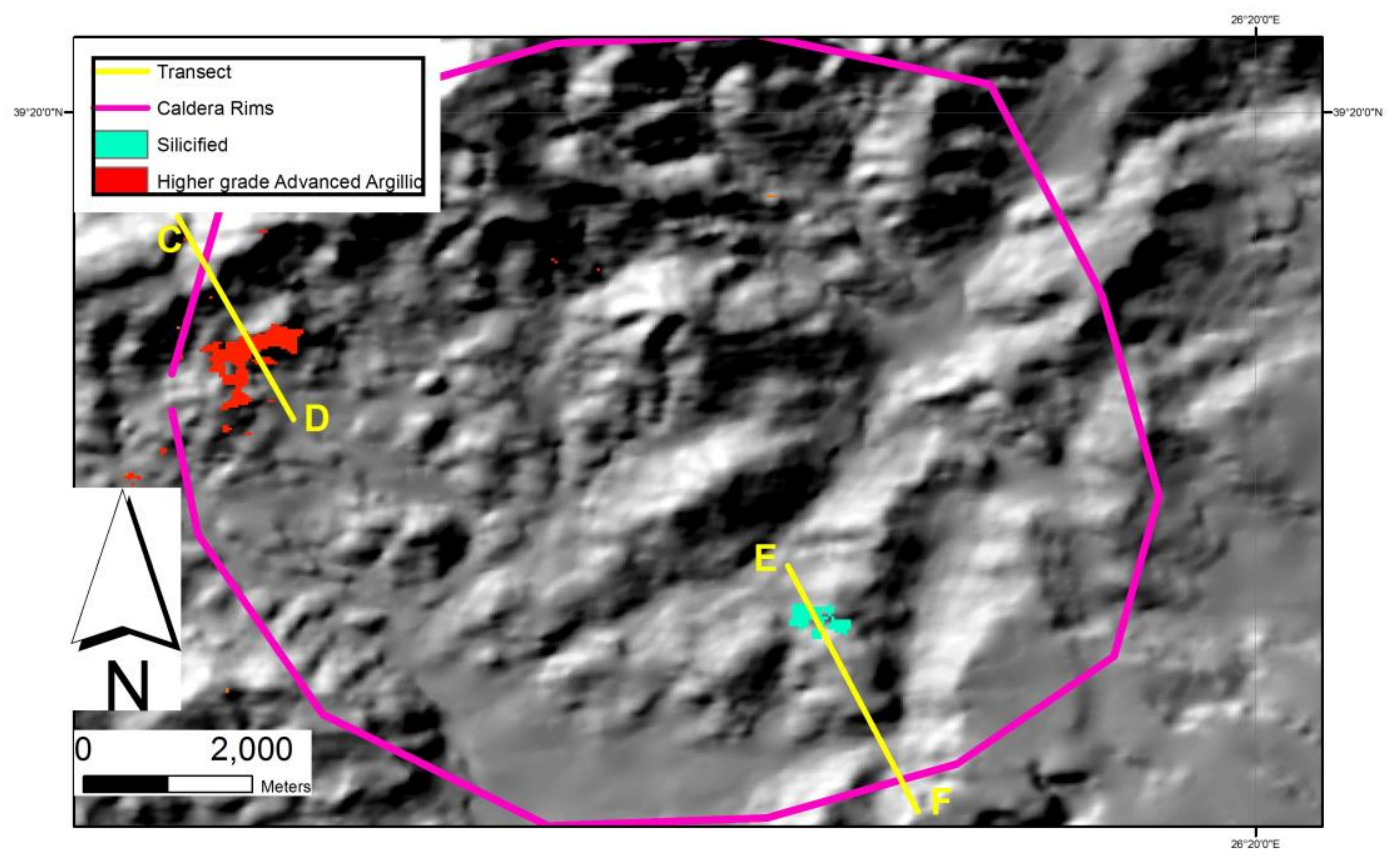

Fig. 11. MF results for ASTER SWIR \& TIR data for Stipsi with Transects C-D and E-F shown. 

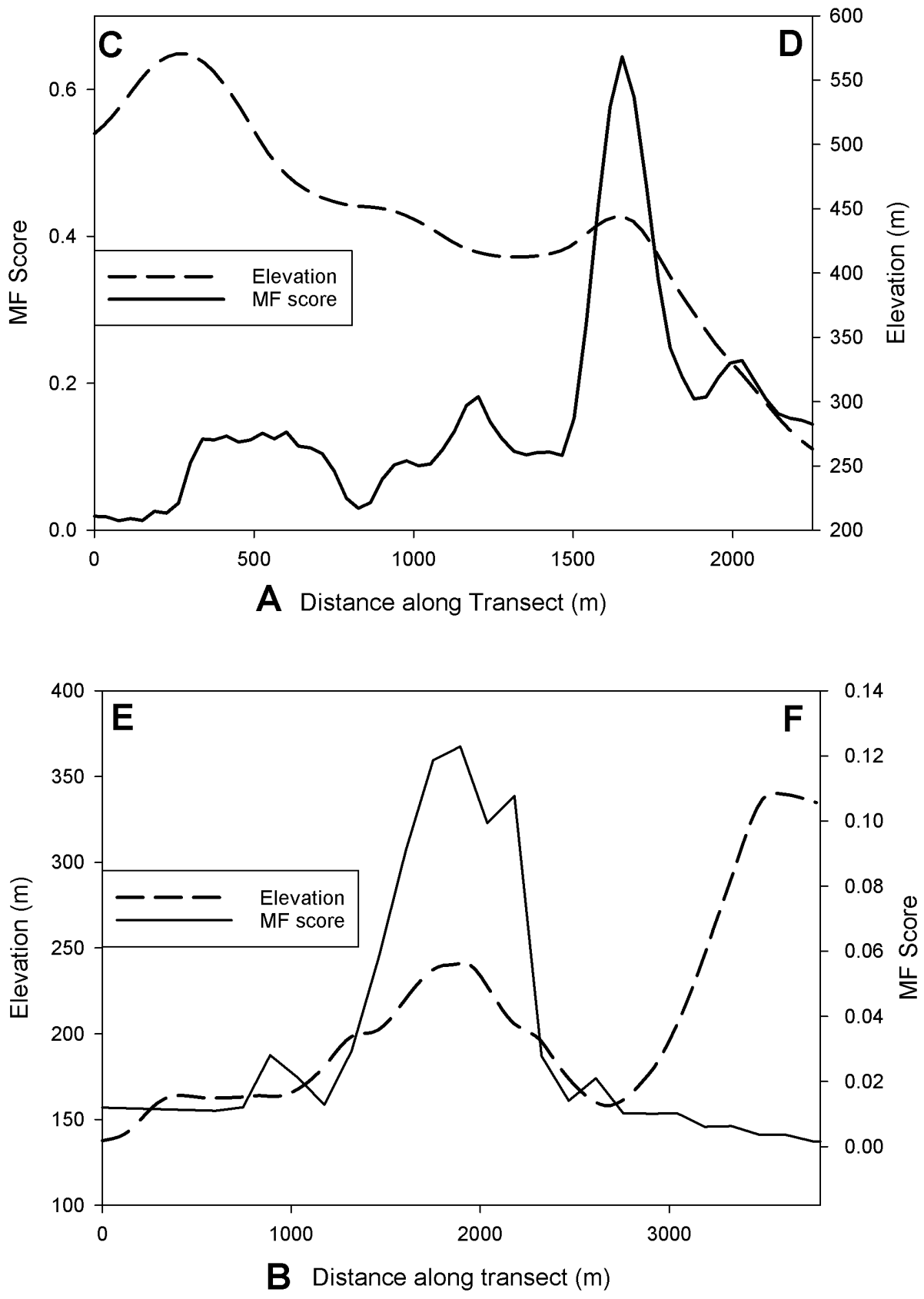

Fig. 12a. Transects (C-D) and Fig 12b. (E-F) across Stipsi caldera showing topography and MTMF scores (see Fig. 9 for transects). 


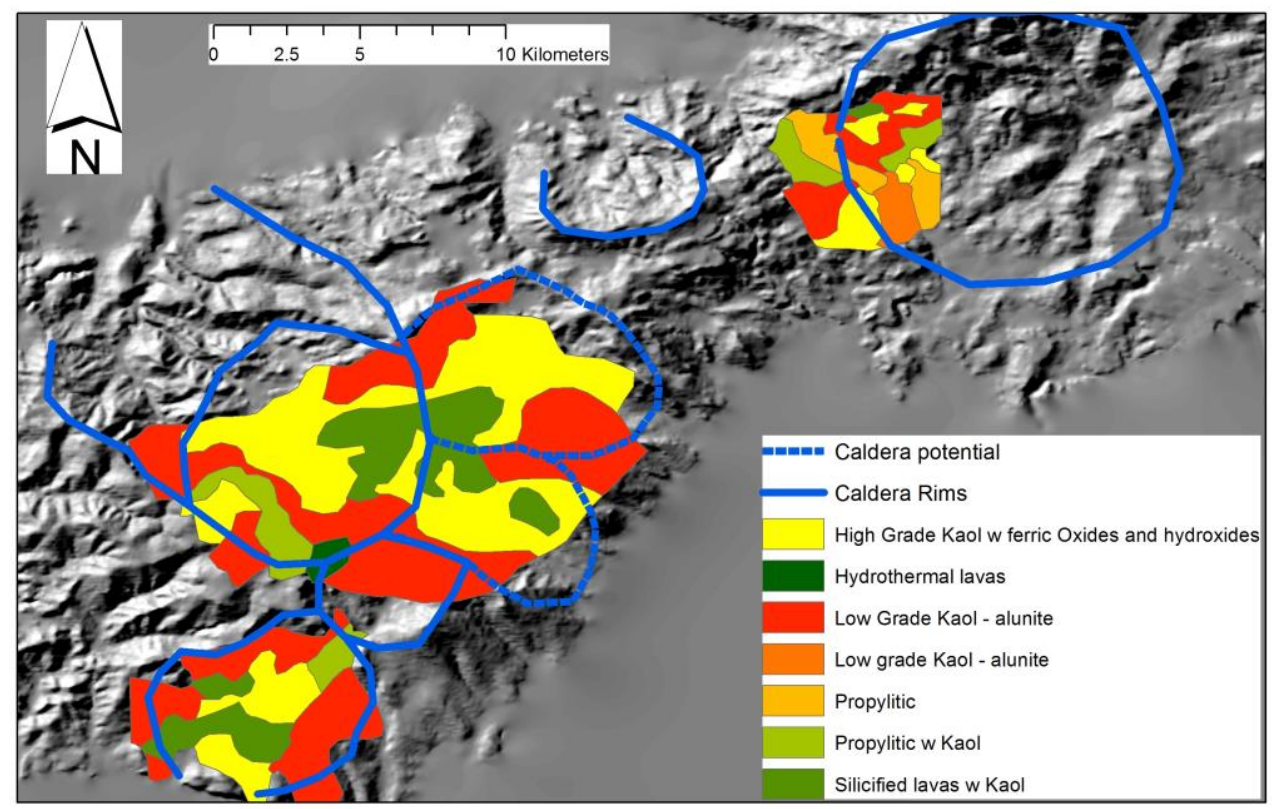

Fig. 13. Field mapped Hydrothermal Alteration zones and caldera rims. 


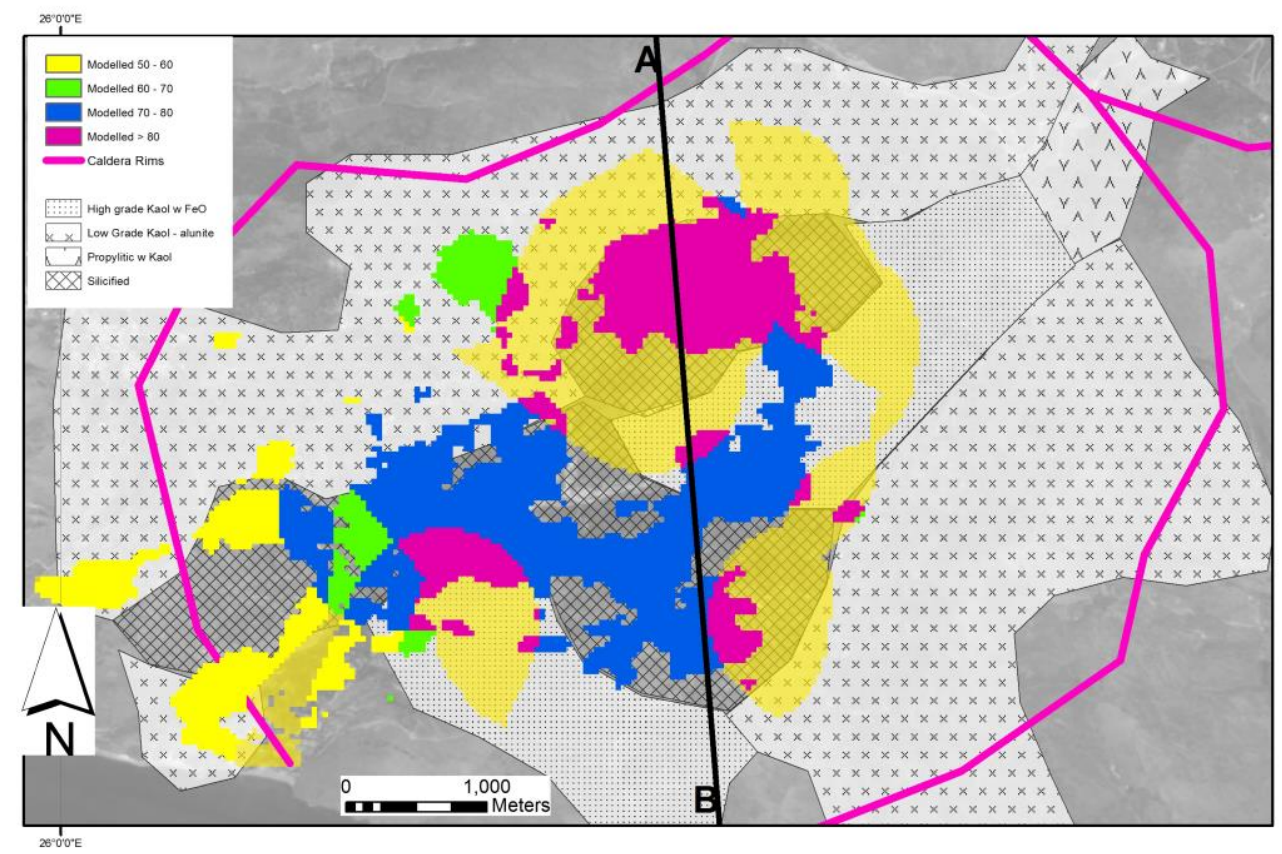

Fig. 14. Results of MPM modelling superimposed on Field mapped Hydrothermal Alteration zones. 


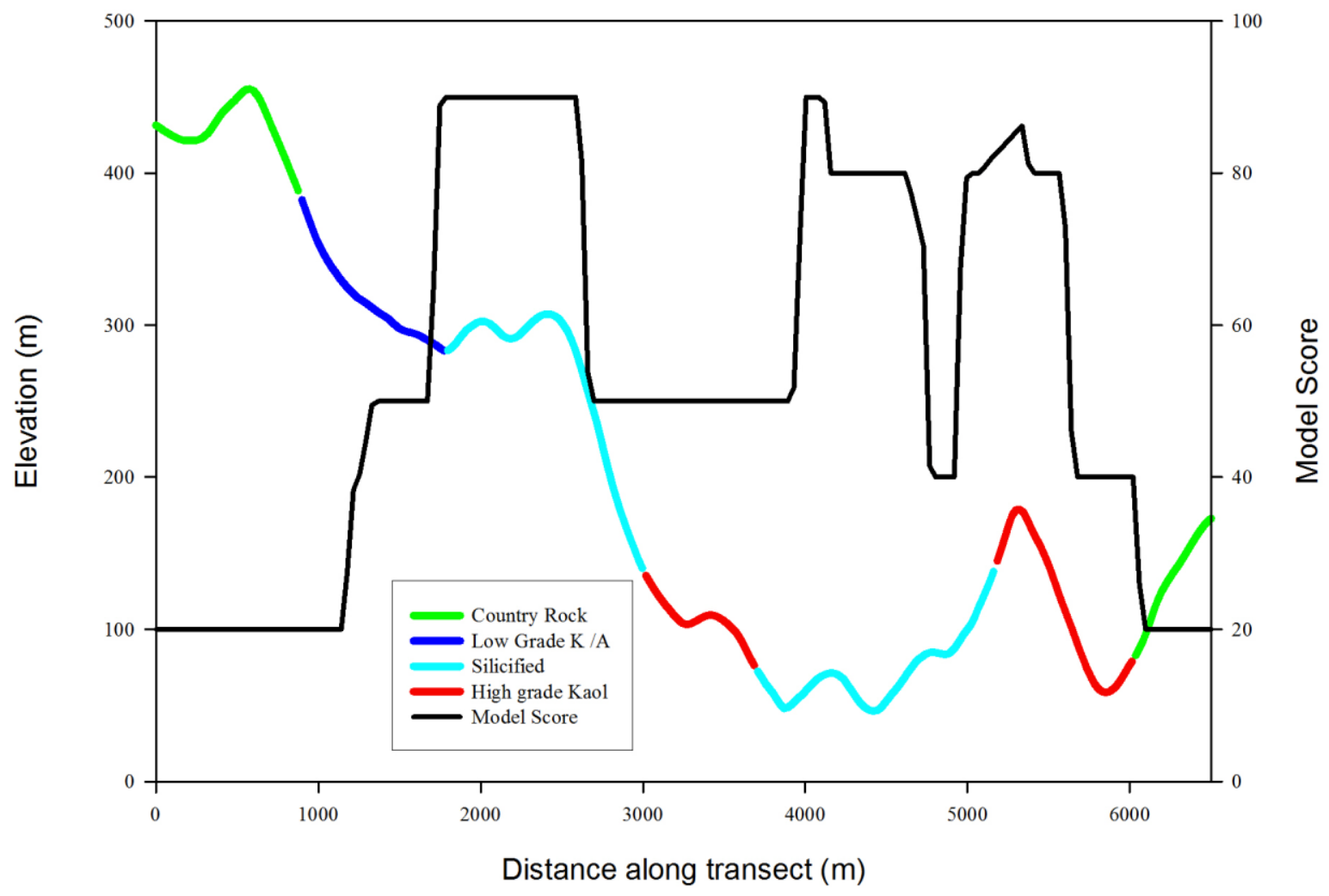

Fig. 15. Transect across Mesotopos caldera showing topography, MPM scores and field mapped contacts. 


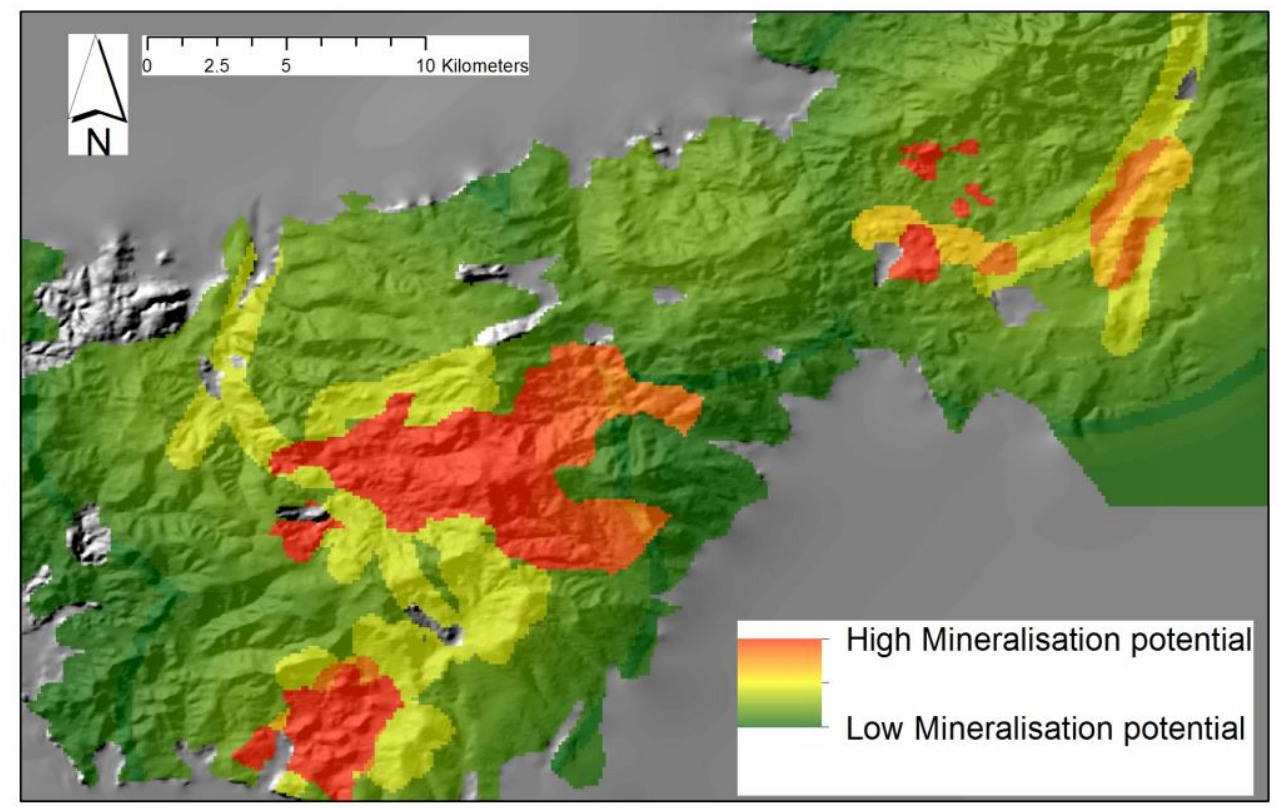

Fig. 16. MPM model results of study area using field mapped hydrothermal alteration zones. 